\title{
KEBUTUHAN MANUSIA DALAM PANDANGAN EKONOMI KAPITALIS DAN EKONOMI ISLAM
}

\author{
RAHMAT GUNAWIJAYA, SE, ME \\ rahmatraystar@gmail.com
}

\begin{abstract}
Abstarct
In Islam, consumption cannot be separated from the role of faith. Faith is an important benchmark because it gives viewpoints that tend to affect the human personality and behaviour. It strongly influences the quantity and quality of consumption in the form of material or spiritual satisfaction, which then shapes the behaviour of market consumption trend. It is certainly in contrast to the principle of the fulfillment of human needs according to a more capitalist economy on the orientation of the material to maximize the production of goods and services to meet human needs. The cornerstone of the philosophy of the capitalist is secularism, separating spiritual and material (or religion and the world) by dikotomis.
\end{abstract}

Keywords: Needs, Consumption, Capitalist Economy, Islamic Economy.

\section{PENDAHULUAN}

\section{Kebutuhan Manusia Dalam Teori Ekonomi}

Ekonomi merupakan aktifitas kegiatan manusia di muka bumi ini, sehingga kemudian timbul motif ekonomi, yaitukeinginan seseorang untuk dapat memenuhi kebutuhan hidupnya. Dalam kehidupan sehari-hari orang cenderung menyamakan kebutuhan (needs) dengan keinginan (wants). Terkadang orang menyebutkan sesuatu sebagai kebutuhan yang harus dipenuhi segera, padahal sesuatu tersebut berupa keinginan yang bisa saja ditunda.

Meningkatnya jenis volume produk industri memudahkan masyarakat bersifat konsumtif dan materialistis. Prilaku konsumtif ini menjadi kebiasaan semua masyarakat dari berbagai kelas sosial. Implikasi sikap konsumtif ini dapat membuat penghasilan masyarakat sebagian besar hanya untuk konsumsi, sehingga tidak ada nya tabungan investasi baik itu untuk dunia dan akhirat seperti zakat dan 
sebagainya $^{1}$

Menurut Rochmawan (2008:4) Kebutuhan manusia banyak dan beraneka ragam, bahkan tidak hanya beraneka ragam tetapi bertambah terus tidak ada habisnya sejalan dengan perkembangan peradaban dan kemajuan ilmu pengetahuan dan teknologi. Satu kebutuhan telah Anda penuhi, tentu akan datang lagi kebutuhan yang lainnya. Kebutuhanadalahkeinginan manusia terhadap barang dan jasa yang harus dipenuhi, dan jika tidak dipenuhi akan berpengaruh terhadap keberlangsungan hidupnya atau bisa menimbulkan dampak negatif contohnya minum obat bagi orang yang sakit, makan nasi bagi orang yang lapar. Hal ini disebut sebagai kebutuhan karena apabila tidak dipenuhi maka bisa menimbulkan dampak negatif seperti sakitnya bertambah parah atau kondisi tubuh yang tidak nyaman akibat rasa lapar².

Keinginan manusia dapat dibedakan kepada dua bentuk yaitu keinginan yang disertai kemampuan untuk membeli barang dan jasa yang diinginkan dan keinginan yang tidak disertai kemampuan untuk membeli barang dan jasa yang diinginkan, keinginan yang disertai kemampuan untuk membeli dinamakan permintaan efektif. ${ }^{3}$

Konsumsi memiliki urgensi yang besar dalam setiap perekonomian. Karena tiada kehidupan manusia tanpa konsumsi. Oleh karena itu kegiatan ekonomi mengarah kepada pemenuhan tuntuan konsumsi bagi manusia. Sebab mengabaikan konsumsi berarti mengabaikan kehidupan dan juga mengabaikan penegakan masusia terhadap tugasnya dalam kehidupan. ${ }^{4}$

Biasanya manusia tidak merasa puas dengan mendapatkan benda yang diperoleh dengan usaha dan prestasi yang dicapai, apabila keinginan dan kebutuhan masa lalu sudah terpenuhi, maka keinginan-keinginan yang baru akan

\footnotetext{
${ }^{1}$ Hasil penelitian Novi Indriyani Sitepu Prilaku Konsumen Indonesia di Jurnal Persfektif Ekonomi Darussalam (2016:104)

2 Sugeng dalam www.ilmuekonom.net. 15 Desember 2014

${ }^{3}$ Yang dimaksud dengan kebutuhan masyarakat adalah keinginan masyarakat untuk memperoleh barang dan jasa. Sebagian barang dan jasa ini diimport dari luar negeri. Tetapi kebanyakan diproduksikan didalam negeri. Keinginan untuk memperoleh barang dan jasa dapat dibedakan kepada dua bentuk: Keinginan yang disertai oleh kemampuan untuk membeli dan Keinginan yang tidak disertai oleh kemampuan untuk membeli. (Sukirno,2001:34)

${ }^{4}$ Sitepu dalam Jurnal Persfektif Ekonomi Islam (2016:92)
} 
wujud. Salah satu contoh seseorang yang belum memiliki kendaraan pribadi, tentu memiliki keinginan memiliki kendaraan pribadi minimal roda dua sebagai alat tranportasi dalam menunjang aktivitas kehidupannya, dan beberapa saat setelah dia berhasil memiliki kendaraan motor roda dua, timbul keinginan baru ingin memiliki mobil pribadi walaupun bekas atau mobil baru dengan harga terjangkau dan setelah dia berhasil memiliki mobil dengan hasil usaha dan kerja kerasnya timbul keinginan baru untuk bisa mendapatkan mobil yang lebih mewah saat pendapatannya meningkat dan seterusnya sehingga kebutuhan manusia sifatnya tak terbatas. Kebutuhan adalah keinginan manusia terhadap suatu barang dan jasa dalam usahanya untuk mempertahankan kehidupannya dimana pemuasannya dapat bersifat jasmani dan rohani. ${ }^{5}$ Keinginan merupakan suatu hal yang ingin kita miliki, namun apabila kita tidak berhasil mendapatkannya maka kelangsungan hidup kita sebagai manusia tidak akan terancam ${ }^{6}$

Artinya kebutuhan bersifat utama sedangkan keinginan bersifat tambahan atau pelengkap dari kebutuhan utama, hal ini bisa kita ilustrasikan sebagai berikut pakaian adalah kebutuhan pokok manusia, dalam aktivitas sehari-hari manusia membutuhkanpakaian yang bersih dan sopan, sedangkan dalam suatu kondisi manusia juga punya keinginan terhadap pakaian yang dikenakannya itu misalnya seorang pemuda ingin memiliki pakaian impor bermerk polo atau cardinal, padahal tanpa menggunakan merek tersebut kebutuhannya sudah tercukupi dengan pakaian yang tanpa merek atau merk lain. Ataupun seseorang pelajar dan yang menginginkan bisa membeli alat komunikasi yang mahal seperti smartphone merk Apple padahal jika dilihat dari urgensi kebutuhannya yang hanya sekedar berkomunikasi lewat telepon ,sms dan aplikasi sosial media dengan menggunakan smartphone merek lain sebenarnya kebutuhannya akan alat komunikasi sudah tercukupi. Akan tetapi karena pengaruh globalisasi dan pergaulan yang konsumtif pelajar tersebut tetap memiliki keinginan untuk memiliki merk apple tersebut.

Konsekuensi yang baik adalah konsekuensi yang memberikan kenikmatan bagi seseorang. Di pihak lain konsekuensi yang buruk adalah konsekuensi yang

\footnotetext{
${ }^{5}$ Nurrofiq.Permasalahan Ekonomi Dalam Kaitannya Dengan Kebutuhan Manusia,Kelangkaan Dan Sistem Ekonomi.aunorofiq46.blogspot.coid. 12 Maret 2015.

${ }^{6}$ ibid
} 
memberikan penderitaan bagi seseorang . Dengan demikian, dalam situasi apapun pedoman tindakan yang benar adalah memaksimumkan kenikmatan dibandingkan penderitaan. Atau dengan kata lain, meminimunkan penderitaan dibandingkan kenikmatan. $^{7}$

Sesuai dengan fitrah manusia, kebutuhan manusia itu tidak terbatas, baik jumlah maupun macamnya. Hal ini disebabkan oleh beberapa faktor berikut ini yaitu :

1. Karena kodrat manusia

Sudah menjadi kodrat bahwa manusia mempunyai sifat yang selalu merasa kekurangan saja dan semakin meningkatnya sarana yang di miliki semakin banyak pula kebutuhan yang di rasakan belum terpenuhi.

2. Faktor alam dan lingkungan

Struktur alam tempat manusia itu berada mendorong manusia itu untuk bertindak atau berbuat menyesuaikan diri dengan alam lingkungannya.

3. Faktor lingkungan masyarakat

Lingkungan masyarakat merupakan faktor dominan. Sebagai penyebab tidak terbatasnya kebutuhan manusia itu. Dalam hal ini sebagai mahluk sosial manusia cenderung ingin menyesuaikan dengan lingkungannya, misalnya orang yang tinggal di lingkungan pedesaan tentu berbeda gaya hidup dan kebutuhannya dengan orang yang tinggal didaerah perkotaan.

4. Faktor perdagangan internasional

Akibat dari pesatnya perdagangan luar negeri atau internasional, maka semakin banyaknya barang-barang luar negeri yang masuk ke negeri kita sendiri, yang menyebabkan kebutuhan dalam negeri baik kebutuhan Negara maupun kebutuhan masyarakatnya meningkat dengan pesat.

5. Faktor demonstracy effect

Sebagai akibat dari lancarnya perdagangan internasional, bukan hanya barang saja yang masuk ke dalam negeri namun kebudayaannya pun ikut berperan ke dalamnya. Yang biasa di sebut dengan demonstrasi effect yaitu sifat atau

\footnotetext{
7Jeremy Betham dalam Asnawi (2015:135)
} 
kebiasaan meniru tingkah laku orang lain atau yang di lihatnya. Misalnya mode pakaian, rambut dan lain-lain.

Dalam ekonomi konvensional sumber masalah ekonomi dimulai dari adanya kebutuhan yang tak terbatas sementara alat pemuas kebutuhan terbatas, atau timbulnya kelangkaan sumber daya, sehingga timbullah kesenjangan antar manusia, dari hal tersebut timbullah kegiatan ekonomi manusia yang bertujuan menciptakan alat pemuas kebutuhan melalui produksi barang-barang dan jasa sesuai dengan prinsip permintaan dan penawaran dan berkembang lebih luas lagi dalam usaha manusia sebagai pelaku ekonomi yang mengoptimalkan tingkat produksi dan konsumsi sekaligus berupaya melakukan efesiensi atau upaya memperoleh hasil yang maksimal dengan pengorbanan sumber daya dan biaya yang serendah-rendahnya. teori ekonomi digambarkan Amran (2016:24) sebagai berikut :

GAMBAR 1

Masalah Perekonomian Di Dunia

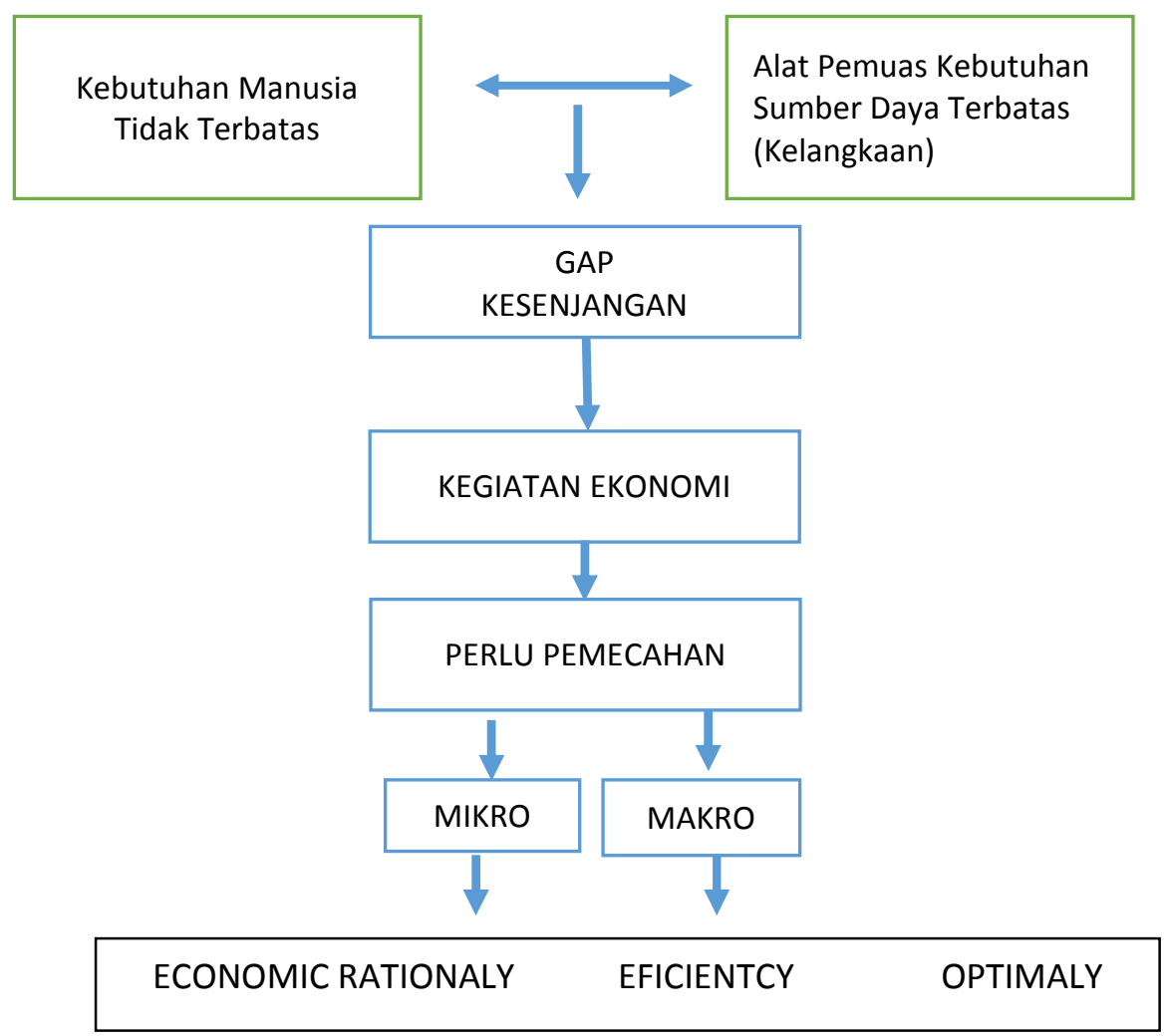

Rahmat Gunawijaya Kebutuhan Manusia Dalam Pandangan.... 
Berdasarkan permasalahan yang menjadi pijakan dalam perekonomian, maka para pakar ekonomi kapitalis melihat ada tiga pokok permasalahan ekonomi yang harus dipecahkan masyarakat, yaitu:

1. Apa yang harus diproduksi dan dalam jumlah berapa (What)?

2. Bagaimana sumber-sumber ekonomi (faktor-faktor produksi) yang tersedia

harus dipergunakan untuk memproduksi barang-barang tersebut (Why) ?

3. Untuk Siapa barang-barang tersebut diproduksi; atau bagaimana barang-barang tersebut dibagikan di antara warga masyarakat (for Whom)?

Menurut Boediono (2003:15) jawaban atas permasalahan benturan antara kebutuhan manusia yang tidak terbatas dengan terbatasnya (langkanya) sumbersumber ekonomi yang tersedia, adalah dengan menambah jumlah produksi barang dan jasa setinggi-tingginya agar kebutuhan manusia yang tidak terbatas dapat diperkecil jaraknya.Meskipun jawaban permasalahan tersebut pada akhirnya harus berbenturan dengan tingkat permintaan konsumen, di mana tingkat permintaan konsumen dipengaruhi oleh banyak faktor, sehingga tingkat produksi secara riil bukanlah produksi sebanyak-banyaknya karena dapat mengakibatkan inefisiensi dan ketidakseimbangan pasar (market disequilibrium), akan tetapi philosofi pemecahan masalah (problem solving) ekonomi dengan cara seperti ini menentukan bagaimana sistem ekonomi kapitalis melihat hakikat permasalahan ekonomi.

Dengan cara pandang ini, maka bagi sistem ekonomi kapitalis, solusi ekonomi yang harus ditempuh secara mikro adalah peningkatan produksi sebanyakbanyaknya,yang berarti berupaya menciptakan pasar konsumen yang sebesarbesarnya dan secara makro mengejar pertumbuhan ekonomi setinggi-tingginya melalui investasi baik dipasar riel atau pasar barang dan jasa maupun di pasar uang maupun pasar modal.

\section{Solusi Makro Ekonomi Kapitalis}


Secara makro yakni bagaimana berusaha menciptakan pertumbuhan ekonomi setinggi-tingginya merupakan suatu target ekonomi yang harus dikejar dan bersifat mutlak. Hanya saja para pakar ekonomi kapitalis dan pemegang kebijakan ekonomi harus realistis dalam menentukan berapa target pertumbuhan ekonomi jika dilihat keadaan ekonomi dari sisi potensi dan permasalahan yang dihadapi suatu negara. ${ }^{8}$

Pertumbuhan ekonomi juga menjadi tolak ukur utama (indikator ekonomi) prestasi ekonomi negara-negara maju dan prestasi pembangunan ekonomi negaranegara berkembang. Di sisi lain berbagai indikator makro ekonomi ditempatkan dalam dua posisi, yaitu mendesain beberapa indikator makro ekonomi (seperti tingkat investasi, suku bunga, kurs mata uang lokal, konsumsi, dan produksi) sebagai lokomotif atau penggerak pertumbuhan ekonomi, dan menjadikan beberapa indikator makro ekonomi lainnya (seperti tingkat pengangguran, kemiskinan) tergantung pada tingkat pertumbuhan ekonomi.

Konsekuensinya, untuk mencapai tingkat pertumbuhan ekonomi sesuai target pertumbuhan ekonomi yang ingin dicapai, maka banyak para ekonom yang memegang kebijakan ekonomi di suatu negara berpendapat tingkat produksi barang dan jasa domestik secara agregat harus ditingkatkan baik dengan cara menarik modal dalam bentuk investasi baik investasi dalam negeri maupun investasi asing. Meningkatkan investasi dalam negeri ditempuh melalui ekspansi kredit perbankan kepada pengusaha dengan menurunkan tingkat suku bunga, meningkatkan pengeluaran pemerintah yang dibiayai dari sumber-sumber dalam negeri dan pinjaman luar negeri. Meningkatkan investasi asing ditempuh dengan membuka kran investasi asing, liberalisasi perdagangan, liberalisasi keuangan, dan liberalisasi berbagai bentuk usaha lokal bagi kepentingan investor. ${ }^{9}$

Mencapai produksi yang tinggi secara agregat harus diikuti peningkatan konsumsi masyarakat. Maka untuk itu para produsen menciptakan suatu rekayasa melalui sarana periklanan dan berbagai upaya lainnya agar dalam masyarakat terbentuk pola hidup konsumtif. Dalam hal ini produsen barang dan jasa selalu

\footnotetext{
${ }^{8}$ Boediono, Pengantar Teori Ekonomi.(Yogyakarta: Gajahmada University Pers, 2003) hal.7

${ }^{9}$ Muttaqin. Kerangka Dasar Sistem Ekonomi Kapitalis. Jurnal Ekonomi Idiologis.8 April 2004.
} 
berusaha agar barang-barang yang diproduksinya dibeli atau dibutuhkan walaupun mungkin bukan kebutuhan yang mendesak, sehingga timbullah mode atau gaya hidup modern yang menyajikan alat-alat yang seakan-akan dibutuhkan konsumen. Di samping itu perbankan juga didorong untuk lebih banyak memberikan kredit konsumtif dengan tingkat bunga yang lebih rendah. Masyarakat diiming imingi kemudahan fasilitas membeli barang secara kredit dari segala macam jenis barang tak hanya barang mahal seperti rumah, dan kendaraan, bahkan handphone dan pakaian juga bisa dikredit pembeliannya dalan sistem ekonomi kapitalis.

Teori prilaku konsumen (consumer behavior) mempelajari bagaimana mereka memilih diantara berbagai pilihan yang dihadapinya dengan memanfaatkan sumber daya (resources) yang dimilikinya. Betham dalam Sulthoni (2015:452) menyatakan bahwa secara umum tidak seorangpun dapat mengetahui apa yang baik untuk kepentingan dirinya kecuali orang itu sendiri.

Menjadikan masalah produksi barang dan jasa setinggi-tinginya sebagai solusi ekonomi dalam sistem ekonomi kapitalis membuktikan bahwa bagi kapitalisme permasalahan ekonomi tidak terletak pada bagaimana memenuhi kebutuhan manusia, akan tetapi terkonsentrasi pada bagaimana memproduksi barang dan jasa. Maksudnya, perhatian sistem ini dalam memecahkan permasalahan ekonomi adalah terhadap zat yang menjadi kebutuhan manusia, bukan terhadap manusia itu sendiri atau dengan kata lain apakah kebutuhan seorang individu itu sudah terpenuhi atau belum bukan menjadi persoalans sistem ekonomi kapitalis, justru yang menjadi persoalan adalah produksi jalan tidak? Atau seberapa banyak kemampuan produksi yang dapat dilakukan?

\section{Konsep Kebutuhan Ekonomi Dalam Islam}

Islam memandang bahwa bumi dan segala isinya merupakan "amanah"dari Allah kepada manusia sebagai khalifah di muka bumi ini, untuk dipergunakan sebesar- besarnya bagi kesejahteraan umat manusia.Untuk mencapai tujuan yang suci ini Allah tidak meninggalkan manusia sendirian tetapi diberikan nya-lah petunjuk melalui para Rosulnya. Dalam petunjuk ini Allah memberikan 
segala sesuatu yang dibutuhkan oleh manusia, baik "aqidah", "ahlak" maupun "syariah".

Dalam Islam tujuan konsumsi adalah memaksimalkan maslahah. Menurut Imam Syatibi dalam Qardhawy (2005:36) istilah maslahah maknanya lebih luas dari sekedar pemenuhan kebutuhan atau kepuasan dalam terminologi ekonomi konvensional.Mencukupi kebutuhan dan bukan memenuhi kepuasan/keinginan adalah tujuan dari aktivitas ekonomi Islam, dan usaha pencapaian tujuan itu adalah salah satu kewajiban dalam beragama. Adapun sifatsifat maslahah sebagai berikut :maslahah bersifat subjektif dalam arti bahwa setiap individu menjadi hakim bagi masing-masing dalam menentukan apakah suatu maslahah atau bukan bagi dirinya. Namun, berbeda dengan konsep nilai guna barang atau utility, kriteria maslahah telah ditetapkan oleh syariah dan sifatnya mengikat bagi semua individu.Maslahah orang per orang akan konsisten dengan maslahah orang banyak. Konsep ini sangat berbeda dengan konsep pareto optimum, yaitu keadaan optimal dimana seseorang tidak dapat meningkatkan tingkat kepuasan atau kesejahteraannya tanpa menyebabkan penurunan kepuasan atau kesejahteraan orang lain.

Menurut istilah umum maslahah adalah: mendatangkan segala bentuk kemanfaatan atau menolak segala kemungkinan yang merusak. Lebih jelasnya manfaat adalah ungkapan dari sebuah kenikmatan atau segala hal yang masih berhubungan denganya, sedangkan kerusakan adalah hal-hal yang menyakitkan atau segala sesuatu yang ada kaitan denganya.Batasan konsumsi dalam islam tidak hanya memperhatikan aspek halal-haram saja tetapi termasuk pula yang diperhatikan adalah yang baik, cocok, bersih, sehat, tidak menjijikan. Larangan israf dan larangan bermegah-megahan.

Begitu pula batasan konsumsi dalam syariah tidak hanya berlaku pada makanan dan minuman saja, tetapi juga mencakup jenis-jenis komoditi lainya. Pelarangan atau pengharaman konsumsi untuk suatu komoditi bukan tanpa sebab. Pengharaman untuk komoditi karena zatnya memiliki kaitan langsung dalam membahayakan moral dan spiritual.Konsumsidalam Islam tidak hanya untuk materi saja tetapi juga termasuk konsumsi sosial yang terbentuk dalam zakat dan 
sedekah. Dalam Islam tujuan pemenuhan kebutuhan manusia terletak pada halal, haram, serta berkah tidaknya barang yang akan dikonsumsi.

\section{KEBUTUHAN MANUSIA DALAM PANDANGAN EKONOMI KAPITALIS DAN EKONOMI ISLAM}

Dalam Islam, konsumsi tidak dapat dipisahkandari peranan keimanan, hal ini menjadi tolak ukur penting karena keimanan memberikan cara pandang yang cenderung mempengaruhi perilaku dan kepribadian manusia. Keimanan sangat mempengaruhi kuantitas dan kualitas konsumsi baik dalam bentuk kepuasan material maupun spiritual, yang kemudian membentuk kecenderungan prilaku konsumsi di pasar.

Ketika keimanan ada pada tingkat yang cukup baik, maka motif berkonsumsi atau berproduksi akan didominasi oleh tiga motif utama tadi; mashlahah, kebutuhan dan kewajiban.Ketika keimanan ada pada tingkat yang kurang baik, maka motifnya tidak didominasi hanya oleh tiga hal tadi tapi juga kemudian akan dipengaruhi secara signifikan oleh ego, rasionalisme (materialisme) dan keinginan-keinganan yang bersifat individualistis.Ketika keimanan ada pada tingkat yang buruk, maka motif berekonomi tentu saja akan didominasi oleh nilai-nilai individualistis (selfishness), ego, keinginan dan rasionalisme.

Pemenuhan kebutuhan manusia dalam pandangan Islam, yaitu senantiasa mengkaitkannya dengan tujuan utama manusia diciptakan yaitu ibadah. Untuk memenuhi kebutuhan ini, maka Allah menghiasi manusia dengan hawa nafsu (syahwat), dengan adanya hawa nafsu ini maka muncul keinginan dalam diri manusia. Allah SWT berfirman :

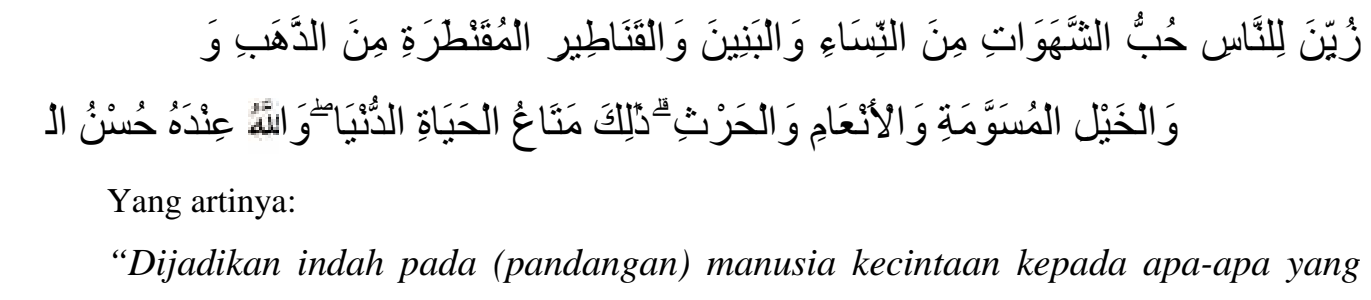
diingini, yaitu: wanita-wanita, anak-anak, harta yang banyak dari jenis emas, perak, 
kuda pilihan, binatang-binatang ternak dan sawah ladang. Itulah kesenangan hidup di dunia, dan di sisi Allahlah tempat kembali yang baik (surga).”[QS. Ali Imran: 14].

Batasan konsumsi dalam Islam tidak hanya memperhatikan aspek halalharam saja tetapi termasuk pula yang diperhatikan adalah yang baik, cocok, bersih, sehat, tidak menjijikan,dan larangan bermegah-megahan.Begitu pula batasan konsumsi dalam syariah tidak hanya berlaku pada makanan dan minuman saja, tetapi juga mencakup jenis-jenis komoditi lainya. Pelarangan atau pengharaman konsumsi untuk suatu komoditi bukan tanpa sebab. Pengharaman untuk komoditi karena zatnya memiliki kaitan langsung dalam membahayakan moral dan spiritual. Misalnya pengharaman terhadap minuman arak karena zat yang terkandungnya dapat merusak tubuh manusia, walaupun mungkin manusia ada yang mempunyai kebutuhan dan keinginan untuk mengkonsumsi minuman arak tersebut, tetapi dari segi kesehatan dan manfaat lebih banyak merusaknya atau lebih banyak mudharatnya dalam pandangan Islam.

Hal ini tentu berbeda jauh dengan prinsip pemenuhan kebutuhan manusia menurut ekonomi kapitalis yang lebih pada orientasi materi bagaimana memaksimalkan produksi barang dan jasa guna memenuhi kebutuhan manusia.landasan filosofi sistem ekonomi kapitalis adalah sekularisme, yaitu memisahkan hal-hal yang bersifat spiritual dan material (atau agama dan dunia) secara dikotomis. Segala hal yang berkaitan dengan dunia adalah urusan manusia itu sendiri sedangkan agama hanyalah mengurusi hubungan antara manusia dengan Tuhannya. Implikasi dari ini adalah menempatkan manusia sebagai sebagai pusat dari segala hal kehidupan (antrophosentris) yaitu manusialah yang berhak menentukan kehidupannya sendiri (Wahyudi,2015:34)

Sebagai perbandingan konsep kebutuhan manusia menurut ekonomi kapitalis dan ekonomi islam dapat digambarkansebagai berikut :

Tabel 1

Perbandingan Konsep Ekonomi Kapitalis dan Ekonomi Islam

\begin{tabular}{|c|l|l|l|}
\hline No & \multicolumn{1}{|c|}{ Keterangan } & \multicolumn{1}{|c|}{ Islam } & \multicolumn{1}{c|}{ Kapitalis } \\
\hline 1 & Sumber & Al-Quran & Daya fikir manusia \\
\hline 2 & Motif & Ibadah & Rasional matearialism \\
\hline
\end{tabular}




\begin{tabular}{|c|l|l|l|}
\hline 3 & Paradigma & Syariah & Pasar \\
\hline 4 & Pondasi dasar & Muslim & Manusia ekonomi \\
\hline 5 & Landasan fillosofi & Falah & Utilitarian individualism \\
\hline 6 & Harta & Pokok kehidupan & Asset \\
\hline 7 & Investasi & Bagi hasil & Bunga \\
\hline 8 & $\begin{array}{l}\text { Distribusi } \\
\text { kekayaan }\end{array}$ & $\begin{array}{l}\text { Zakat, infak, shodaqoh, } \\
\text { hibah, hadiah, wakaf } \\
\text { dan warisan. }\end{array}$ & Pajak dan tunjangan \\
\hline 9 & Konsumsi & $\begin{array}{l}\text { Maslahah, kebutuhan } \\
\text { dan kewajiban }\end{array}$ & $\begin{array}{l}\text { Egoism, materialism, dan } \\
\text { rasionalisme }\end{array}$ \\
\hline 10 & Mekanisme pasar & $\begin{array}{l}\text { Bebas dan dalam } \\
\text { pengawasan }\end{array}$ & Bebas \\
\hline
\end{tabular}

Berdasarkan perbandingan sistem ekonomi islam dan sistem ekonomi kapitalis terletak pada sumber utama dimana dalam Islam, semua kegiatan ekonomi harus bersumber pada tuntunan agama yaitu Al Quran sedangkan pada sistem ekonomi kapitalis bersumber pada pikiran manusia atau menganut paham rasionalitas tanpa mempertimbangkan sisi spiritual manusia sebagai mahluk ciptaan Allah SWT. Menurut ilmu ekonomi kapitalis, sesuai dengan pahamnya tentang rational economics man, tindakan individu dianggap rasional jika tertumpu kepada kepentingan diri sendiri (self interest)yang menjadi satu-satunya tujuan bagi seluruh aktivitas. Dalam ekonomi kapitalis, perilaku rasional dianggap ekuivalen (equivalent) dengan memaksimalkan utiliti. Ekonomi konvensional mengabaikan moral dan etika dalam pembelanjaan dan unsur waktu adalah terbatas hanya di dunia saja tanpa pmempertimbangkan hari akhirat. ${ }^{10}$

Kapitalisme berusaha mewujudkan suatu ilmu ekonomi yang bersifat objektif, bebas dari petimbangan moralitas dan nilai, dan karenanya berlaku universal. Ilmu ekonomi telah dideklarasikan sebagai kenetralan yang maksimal di antara hasil akhir dan independensi atasyang pertimbangan normatif. Untuk mewujudkan obyektivitas ini, maka positivism telah menjadi bagian integral dari paradigma ilmu ekonomi. Positivism menjadi sebuah keyakinan bahwa setiap pernyataan ekonomi yang timbul harus mempunyai pembenaran dari fakta

\footnotetext{
${ }^{10}$ Wahyudi, Perbedaan Mendasar Ekonomi Islam dan Ekonomi Kapitalis.(Madura: Ekonomi Pembangunan Universitas Trunojoyo,2015).
} 
empiris. Paham ini secara otomatis mengabaikan peran agama dalam ekonomi, sebab dalam banyak hal, agama mengajarkan sesuatu yang bersifat normatif.

Dalam pandangan ekonomi kapitalis,nilai guna barang, utilitas adalah jumlah dari kesenangan atau kepuasan relatif yang dicapai. Dengan jumlah ini, seseorang bisa menentukan meningkat atau menurunnya utilitas, dan kemudian menjelaskan kebiasaan ekonomis dalam koridor dari usaha untuk meningkatkan kepuasan seseorang.

Dalam ilmu ekonomi tingkat kepuasan (utility function) digambarkan oleh kurva indiferen (indifference curve). Biasanya yang digambarkan adalah nilai kegunaan antara dua barang (atau jasa) yang keduanya memang disukai konsumen. Menurut Soeharno (2006:43-44) kurva indeferen adalah kurva yang menggambarkan berbagai kombinasi dari barang yang dikonsumsi oleh konsumen dengan manfaat yang sama. Hal ini bisa dimisalkan pada saat konsumen ingin mengkonsumsi dua jenis minuman yang diasumsikan memiliki tingkat kepuasan yang sama, pada saat konsumen lebih menyukai konsumsi kopi, maka jumlah konsumsi teh akan berkurang dan sebaliknya dengan nilai tingkat kepuasan yang sama, sebagaimana digambarkan dalam kurva berikut :

Gambar 1

\section{Bentuk Kurva Indiferens}

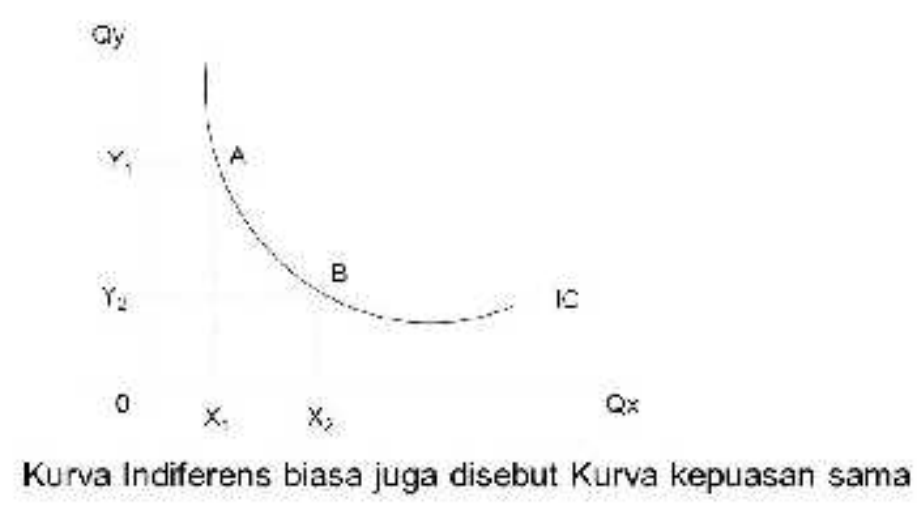

Rahmat Gunawijaya Kebutuhan Manusia Dalam Pandangan.... 
Tujuan aktifitas konsumsi adalah memaksimalkan kepuasan (utility) dari mengkonsumsi sekumpulan barang/jasa yang disebut 'consumption bundle' dengan memanfaatkan seluruh anggaran/ pendapatan yang dimiliki. Dalam ekonomi kapitalis kemampuan konsumen untuk memaksimalkan kebutuhannya dibatasi oleh daya beli atau nilai yang harus dikorbankan untuk memenuhi kebutuhan orang tersebut.Menurut Mankiw (2012:63) "the cost of something is what you give up to get it" (biaya merupakan apa yang dikorbankan untuk memperoleh sesuatu). Untuk mendapatkan sesuatu yang kita butuhkan dan inginkan terkadang kita harus mengorbankan sesuatu, biasanya berupa uang untuk membeli sesuatu tersebut.

Dalam kehidupan sehari-hari dapat kita umpamakan manusia dihadapi oleh pilihan mengorbankan sesuatu dengan kemampuan atau sumber daya yang dimiliki dalam hal ini uang yang dimiliki untuk memenuhi kebutuhan tersebut sebagai contoh saat karyawan ingin membeli baju baru dan sepatu baru dengan simpanan gajinya yang sebesar 500.000 rupiah disaat yang sama motor yang dia gunakan untuk bekerja mengalami kerusakan dan harus masuk bengkel motor dengan biaya sebesar 500.000 rupiah. Tentunya karyawan tersebut dihadapi pada dua pilihan yakni membetulkan motor yang digunakan untuk bekerja dengan biaya 500.000 rupiah dengan konsekuensi menunda keinginan membeli baju dan sepatu baru atau tetap membeli baju dan sepatu baru dengan biaya pengorbanan (opportunity cost)tidak bisa menggunakan motor untuk bekerja.

Dalam Islam, semua kegiatan manusia dilandasi oleh syariah yang telah ditetapkan oleh Allah SWT sebagai pencipta alam semesta. Chapra (199:24) menyebutnya dengan Ekonomi Tauhid yang secara umum dapat dikatakan sebagai divine economics. Cerminan watak "Ketuhanan" ekonomi Islam terdapat pada aspek aturan atau sistem yang harus dipedomani oleh para pelaku ekonomi. Ini didasarkan pada keyakinan bahwa semua faktor ekonomi termasuk diri manusia pada dasarnya adalah kepunyaan Allah, dan kepadaNya (kepada aturanNya) dikembalikan segala urusan, sebagaimana firman Allah dalam surah Al - Imran Ayat 109: 

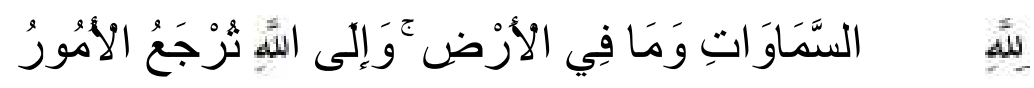

Artinya Kepunyaan Allah-lah segala yang ada di langit dan di bumi; dan kepada Allahlah dikembalikan segala urusan.

Melalui aktivitas ekonomi, manusia dapat mengumpulkan nafkah sebanyak mungkin, tetapi tetap dalam batas koridor aturan agama yang sudah ditetapkan Allah untuk kebaikan seluruh umat manusia, setiap makhluk hidup telah disediakan rezekinya selama ia berikhitiar atau berusaha untuk mendapatkannya. Namun Allah tak pernah menjamin kesejahteraan ekonomi tanpa manusia tadi melakukan usaha.

Kepuasan dalam Islam meliputi kepuasan konsumtif dan kepuasan kreatif, kepuasan konsumtif akan menghasilkan kepuasan kreatif, sebab konsumsi yang dilakukan seorang muslim akan memberikan kekuatan fisik, sehingga ia akan lebih kreatif ${ }^{11}$

Sebagai ekonomi yang berketuhanan maka Ekonomi Islam menurut $\mathrm{Al}$ Faruqi dalam Chapra (1999:271) mempunyai sumber "nilai-nilai normatifimperatif", sebagai acuan yang mengikat. Dengan mengakses kepada aturan Ilahiah, setiap perbuatan manusia mempunyai nilai moral dan ibadah. Setiap tindakan manusia tidak boleh lepas dari nilai, yang secara vertikal merefleksikan moral yang baik, dan secara horizontal memberi manfaat bagi manusia dan makhluk lainnya.

Perilaku konsumen dalam Islam menekankan pada konsep dasar bahwa manusia cenderung untuk memilih barang dan jasa yang memberikan maslahah maksimum. Hal ini merupakan kodrat manusia yang juga banyak dikaji oleh para ekonom. Pendekatan studi kepribadian konsumen dikembangkan oleh Yazid Al Bustami dan Ibnu Arabi dalam Sultoni (2015:453) Dengan menggunakan pendekatan akhlak bukan berarti menjauhkan diri dari konsumen dari hal-hal yang berbau keduniawian seperti zuhud. Oleh sebahagian kalangan zuhud diartikan

\footnotetext{
${ }^{11}$ Kepuasan kreasi dapat diketahui dari Perintah Nabi M uhammad SAW yaitu " berhenti makan sebelum kenyang" $\mathrm{Hal}$ ini disebabkan pada saat itu kondisi kreatif dapat diperoleh (Sulthoni,2015:467)
} 
meninggalkan dunia. Padahal pemahaman ini tidak mungkin dilakukan oleh manusia siapapun dia karena dia sendiri hidup didunia. Yang benar adalah bahwa karena zuhudnya seseorang tidak materialistis. Dia membutuhkan materi tetapi tidak rakus dan tamak. Dia cukup puas dengan keadaan yang dia terima saat ini.

Dalam rangka pemenuhan kebutuhan atau kepentingan manusia tersebut menurut Qardhawy (2005:27) harus mempertimbangkan kaidah - kaidah berikut :

1. Mendahulukan kepentingan yang sudah pasti atas kepentingan yang baru diduga adanya, atau masih diragukan.

2. Mendahulukan kepentingan yang besar atas kepentingan yang kecil

3. Mendahulukan kepentingan sosial atas kepentingan individual

4. Mendahulukan kepentingan yang banyak atas kepentingan yang sedikit.

5. Mendahulukan kepentingan yang berkesinambungan atas kepentingan yang yang sementara atau insidentil

6. Mendahulukan kepentingan inti dan fundamental atas kepentingan yang bersifat formalitas atau tidak penting.

7. Mendahulukan kepentingan masa depan yang kuat atas kepentingan kekinian yang lemah.

Berdasarkan kaidah dalam rangka pemenuhan kebutuhan manusia maka, sesuai dengan prinsip maslahah yang berarti mengutamakan hal yang mendatangkan kebaikan, setiap manusia dalam memenuhi kebutuhannya haruslah memiliki skala prioritas dengan menentukan mana yang merupakan kebutuhan yang utama dan mendesak dan mana kebutuhan yang bisa ditunda pemenuhannya dalam rangka mencukupi kebutuhan hidup agar sejahtera dunia dan akhirat sesuai tuntunan syariat Islam.

Bagi para ekonom muslim, konsep maslahahdianggap lebih obyektif dan adil dari pada konsep utilitas atau nilai guna barang dan jasa yang dibutuhkan dalam konsep ekonomi kapitalis untuk menganalisis perilaku para pelaku ekonomi. Meskipun maslahah mungkin akan menyisakan sedikit subyektifitas, namun subyektifitas tersebut tidak membuatnya samar seperti yang terjadi dalam konsep utilitas. Ada beberapa alasan mengapa konsepmaslahah dianggap lebih 
baik dari pada konseputilitas, yaitu jika dikaji unsur manfaat dan kebaikan bagi konsumen.

Maslahah memang bersifat subyektif berdasarkan kebutuhan individu, karena setiap individu dapat menentukan sesuatu yang baik maslahah bagi diri mereka sendiri. Akan tetapi kriteria untuk menentukan maslahah ini lebih jelas dan terarah, dari pada subyektifitas yang ada pada konsep utilitas. Dalam konsep utilitas, alkohol (minuman keras) bisa jadi mengandung utilitas tapi bisa juga tidak, relatif pada individu masing-masing. Namun dalam Ekonomi Islam, karena alkohol tidak mengandung kemaslahatan dan jelas kontradiktif dengan alkuliyyah al-khamsah maka jelas alkohol tidak akan dikonsumsi.

Dengan menggunakan konsep mashalah dalam pemenuhan kebutuhan manusia konflik kepentingan antara kepentingan individu dan kepentingan sosial dapat dihindari, atau setidaknya diminimalisir. Hal ini karena kriteria maslahah antara individu dan sosial dapat disinkronkan, sesuai yang tertuang dalam aturanaturan syar'i. Konsep ini berlaku pada semua aktifitas ekonomi di masyarakat, baik itu dalam proses produksi dan konsumsi. Berbeda halnya dengan ekonomi kapitalis dimana utilitas adalah tujuan dari konsumsi; sedangkan profit atau keuntungan adalah tujuan dari proses produksi. Artinya dalam pandangan Islam kebutuhan dan keinginan manusia dilandasi syariat agama dengan mengutamakan asas manfaat dan nilai-nilai kebaikan yang terkandung dalam usaha memenuhi kebutuhan tersebut, hal ini berbeda dengan konsep ekonomi kapitalis yang lebih mengutamakan pemenuhan kebutuhan materi berdasarkan nilai guna dan kepuasan yang diinginkan konsumen.

Dalam ekonomi kapitalis manusia diperbolehkan menumpuk harta sebesar-besarnya melalui usaha dan kerja keras,tanpa kewajiban untuk menyisihkan sebagian harta yang diperolehnya kepada manusia lain yang sedang dalam keadaan kekurangan, kewajiban manusia terhadap kepentingan manusia lain diatur oleh negara melalui nilai yang diperoleh dari utilitas yang diperolehnya dalam menggunakan fasilitas umum yang dibangun negara, sehingga timbullah pajak, dan restribusi yang harus dibayar masyarakat ke negara di zaman sekarang yang peruntukan dananya adalah untuk membiayai fasilitas umum seperti jalan, 
jembatan,fasilitas pendidikan dan fasilitas kesehatan, dan layanan birokrasi yang dikelola oleh negara.

Menurut Manan (1997:50) Islam tidak pernah melupakan unsur materi dalam memakmurkan dan meningkatkan taraf hidup manusia, perintah Islam mengenai konsumsi dikendalikan oleh lima prinsip yaitu :

1) Keadilan

2) Kebersihan

3) Kesederhanaan

4) Kemurahan Hati

5) Moralitas

Dalam ekonomi Islam manusia dianjurkan untuk berusaha dan bekerja mencukupi kebutuhan hidupnya, kekayaan harta seseorang tidak boleh dipergunakan untuk kepentingan diri sendiri, tetapi harus disisihkan sebagian dari nilai perolehannya untuk kepentingan zakat, infaq dan shadaqah bagi kepentingan umat. Setiap bagian harta kekayaan individu ada kadar dan takaran persentase yang wajib dizakatkan dalam rangka membersihkan harta tersebut untuk mendapat ridha Allah, sekaligus menggerakkan pemberdayaan umat dalam rangka pengentasan kemiskinan dan mengurangi kesenjangan sosial antara kaum kaya dan kaum miskin, karena hanya orang miskin saja yang wajib menerima zakat.

Sistem ekonomi Islam lahir sebagai sistem ekonomi yang dapat merealisasikan keadilan antara hak-hak individu dengan hak-hak kolektif suatu masyarakat yang ada saat ini, sistem ekonomi Islam adalah keseimbangan antara kebutuhan individu dan kebutuhan masyarakat sebagaimanaditegakkannya dalam berbagai pasangan lainnya, yaitu dunia dan akhirat, jasmani dan ruhani,akal dan nurani sebagaimana petunjuk yang diberikan Alllah dalam Al Quran.

\section{KESIMPULAN}

Sebagai mahluk sosial kebutuhan dan keinginan manusia adalah tidak terbatas, sedangkan alat atau sumber daya pemuas kebutuhan manusia sangat terbatas, selain itu manusia juga dibatasi oleh aturan-aturan dan kaidah-kaidah dalam hal dan cara memperoleh alat pemenuhan kebutuhan tersebut. Dalam 
prinsip ekonomi kapitalis pemenuhan kebutuhan manusia bersifat individualisme dan rasionalisme beorientasi materi bagaimana memaksimalkan produksi barang dan jasa semaksimal mungkin dan seefesien mungkin guna memenuhi kebutuhan manusia tetapi kurang mempertimbangkan aspek moral dan etika tentang tata cara memperoleh dan memenuhi kebutuhan manusia tersebut. Pemenuhan kebutuhan manusia sangat terkait dengan pertumbuhan ekonomi dimana dengan permintaan konsumsi barang dan jasa yang tinggi maka akan meningkatkan penawaran barang dan jasa tersebut dalam bentuk peningkatan atau penambahan faktor-faktor produksi yang diharapkan meningkatkan investasi modal dan tenaga kerja yang selanjutnya meningkatkan upah atau pendapatan yang memicu kenaikan daya beli dalam perekonomian masyarakat.

Dalam Islam pemenuhan kebutuhan manusia tidak lepas dari kodrat manusia sebagai mahluk ciptaan Allah, yang diatur secara syariat oleh agama Islam dimana manusia dalam rangka memenuhi kebutuhannya harus berprinsip kemashalatan atau usaha dalam rangka untuk memperoleh kebaikan di dunia dan diakhirat dengan mempertimbangkan manfaat dan asas halal dan haramnya jenis kebutuhan manusia, atau boleh tidaknya kebutuhan itu dipenuhi.

Pemenuhan kebutuhan manusia dalam Islam tidak hanya memenuhi kebutuhan duniawi seperti makan,minum,pakaian,perumahan, dan kendaraan transportasi, akan tetapi manusia juga harus memenuhi kebutuhan rohani atau kebutuhan spiritual agar manusia menjadi manusia yang berahlak baik,berguna, dan bermanfaat bagi sesama manusia baik di dunia maupun di akhirat. 


\section{Daftar Pustaka}

Amran. (2016). Penyelesaian Sengketa Ekonomi Syariah. Jakarta: Prenada Media Group.

Asnawi, Ahmad. (2015). Sejarah Para Filsuf Dunia. Yogyakarta: Indoliterasi.

Boediono. (2012). Ekonomi Mikro. Yogyakarta: BPFE UGM.

Chapra, Umar. (1999). Islam dan Tantangan Ekonomi. Jakarta: The Islamic Foundation.

Manan. (1997). Teori Dan Praktek Ekonomi Islam. Yogyakarta: Dana Bhakti Primayasa.

Mankiw, Gregory. (2012). Pengantar Ekonomi Mikro. Jakarta: Salemba Empat.

Muttaqin, Hidayatullah. (2004). Kerangka Dasar Sistem Ekonomi Kapitalis. Jurnal Ekonomi Idiologis.

Nurrofiq. (2015, Maret 12). Permasalahan Ekonomi Dalam Kaitannya Dengan Kebutuhan Manusia, Kelangkaan dan Sistem Ekonomi. Retrieved February 20, 2017, from www.aunurrofiq46.blogspot.co.id.

Qarhawy, Yusuf. Al. (2005). Fiqh Prioritas. Jakarta: Robbani Press.

Rochmawan, Laksono Tri. (2008). Pengantar Ekonomi Mikro. Semarang: Anindya.

Sitepu, Novi Indriyani. (2016). Prilaku Konsumsi Islam di Indonesia. Jurnal Persfektif Ekonomi Darussalam Volume 2 No.1, 92-106.

Sugeng. (2014, December 15). Kebutuhan Ekonomi. Retrieved February 21, 2017, from www.ilmuekonom.net.

Sukirno, Sadono. (2001). Ekonomi Mikro. Jakarta: Grafisindo.

Sulthoni, Hasan. (2015). Prilaku Konsumen Dalam Perfekif Ekonomi Islam: Teori Dan Praktek. Jurnal Ekonomi Syariah STAI Muhammadiyah Tulungagung Volume II Nomor 2, 451-457.

Wahyudi. (2015). Ekonomi Pembangunan. Madura: Universitas Trunojoyo Press. 